\title{
PENGARUH UKURAN BUTIR BRIKET CAMPURAN SEKAM PADI DENGAN SERBUK KAYU JATI TERHADAP EMISI KARBON MONOKSIDA (CO) DAN LAJU PEMBAKARAN
}

\author{
SRI SURYANINGSIH*, OTONG NURHILAL, KOMALA AFFIYANTI AFFANDI \\ Depertemen Fisika Fakultas MIPA Universitas Padjadjaran \\ Jl. Raya Bandung-Sumedang Km 21, Jatinangor 45363 \\ *email : sri@phys.unpad.ac.id
}

\begin{abstract}
Abstrak. Salah satu bahan bakar alternatif yang dapat digunakan dalam pemenuhan kebutuhan energi di Indonesia adalah briket dari limbah biomassa. Dalam pemanfaatannya, briket dapat menghasilkan emisi karbon monoksida yang berbahaya bagi kesehatan manusia yang dihasilkan dari proses pembakaran tidak sempurna carbon dengan oksigen. Tujuan penelitian ini untuk mengetahui emisi karbon monoksida (CO) dan laju pembakaran dari briket campuran sekam padi dengan serbuk gergaji kayu jati dan pengaruhnya terhadap ukuran butir briket. Metodologi penelitian meliputi pengeringan bahan, karbonisasi bahan, penghalusan dan penyaringan bahan 40 mesh (420 $\mu \mathrm{m}), 60$ mesh $(250 \mu \mathrm{m})$, dan 100 mesh $(149 \mu \mathrm{m})$, pencetakan dan pengepresan briket, serta pengeringan briket. Selanjutnya dilakukan pengujian emisi karbon monoksida dan laju pembakaran pada briket. Hasil emisi karbon monoksida (CO) semakin berkurang ketika ukuran butir yang dimiliki briket yang semakin kasar. Variasi pencampuran bahan sekam padi dan serbuk gergaji kayu jati pada perbandingan 50:50 dengan ukuran butir 40 mesh menghasilkan emisi karbon (CO) paling rendah sebesar 509 ppm / sekon. Semakin kasar ukuran briket maka laju pembakaran yang dihasilkan semakin cepat dan briket semakin cepat habis terbakar, namun nilai kalor yang dihasilkan masih rendah berkisar antara 3.420 - $4.889 \mathrm{kal} / \mathrm{gr}$. Laju pembakaran yang paling tinggi terdapat pada sampel briket campuran sekam padi dengan serbuk gergaji kayu jati pada perbandingan 50:50 dengan ukuran butir briket 40 mesh adalah sebesar $0,0138 \mathrm{gram} / \mathrm{sekon}$.
\end{abstract}

Kata kunci : briket, sekam padi, serbuk kayu jati, emisi karbon monoksida

Abstract. One alternative fuel that can be used to fulfill the energy needs in Indonesia is briquettes from biomass waste. In its application, the briquettes can produce carbon monoxide emissions that are harmful to human health resulting from the imperfect combustion of carbon with oxygen. The purpose of this research is investigation the carbon monoxide ( $\mathrm{CO}$ ) emission and combustion rate of the rice husk mixture with sawdust from teak wood and its effect to briquette grain size. The research methodology includes material drying, material carbonization, refining and filtering of 40 mesh (420 $\mu \mathrm{m}), 60 \mathrm{mesh}(250 \mu \mathrm{m})$, and 100 mesh $(149 \mu \mathrm{m})$ materials, briquette printing and pressing, and briquette drying. Further testing of carbon monoxide emissions and combustion rate on briquettes. The result of carbon monoxide $(\mathrm{CO})$ emissions decreases as the grain size of the briquettes becomes increasingly coarse. Variations of mixing of rice husks and teak sawdust on a ratio of 50:50 using 40 mesh grain size resulted the lowest carbon emission (CO) of $509 \mathrm{ppm} / \mathrm{second}$. The more coarse about the size of the briquette grain the faster the burning rate and the faster the briquette burns out, but the resulting calorific value is still low ranging from 3,420 - 4,889 cal / gr. The highest burning rate was found on rice husk briquette mixture with teak sawdust at ratio 50:50 using 40 mesh briquette grain size was 0.0138 grams/second.

Keywords : briquette, rice husk, teak sawdust, carbon dioxide emission 


\section{Pendahuluan}

Kebutuhan dasar manusia terhadap energi yang semakin meningkat seiring dengan bertambahnya jumlah penduduk di Indonesia. Bahan bakar minyak (BBM) yang berasal dari fosil masih mendominasi dalam pemenuhan kebutuhan energi di Indonesia yaitu sebesar 52,50\% dan masih disubsidi, sehingga menjadi beban yang sangat berat bagi pemerintah. Untuk mengurangi beban subsidi tersebut pemerintah berusaha mengurangi ketergantungan kepada energi bahan bakar minyak dengan mencari dan mengembangkan sumber energi lain yang murah dan mudah didapat yaitu dengan memanfaatkan sumber energi baru terbarukan salah satunya biomassa [1].

Biomassa merupakan bahan yang dapat diperoleh dari tanaman baik secara langsung maupun tidak langsung dan dimanfaatkan sebagai energi dalam jumlah yang besar [3]. Biomassa dapat berasal dari tumbuhan ataupun hewan, produk dan limbah pertanian, perkebunan, kehutanan, perternakan, dan perikanan [4]. Penyusun biomassa pada umunya terdiri dari selulosa, hemiselulosa, dan lignin. Kandungan selulosa pada biomassa berpengaruh pada nilai karbon terikat dalam pembuatan briket. Semakin tinggi kadar karbon terikat, maka akan menghasilkan nilai kalor yang semakin besar [5].

Biomassa Sekam padi dapat digunakan sebagai sumber energi panas akan tetapi dalam pemanfaatannya masih memiliki kelemahan yaitu menimbulkan asap pada saat pembakaran dan cepat habis terbakar, untuk itu pemanfaatan sekam padi dapat divariasikan dengan dimampatkan sehingga bentuknya kompak, hemat tempat, dan praktis digunakan dalam bentuk briket. Briket arang merupakan bahan bakar padat terbuat dari biomassa yang diarangkan dengan proses karbonisasi [6]. Bahan briket dari sekam padi masih memiliki nilai kalor yang relatif kecil jika dibandingkan nilai kalor menurut spesifikasi bahan bakar padat untuk rumah tangga di Indonesia (SNI 01-6235-2000) yaitu $5000 \mathrm{kal} / \mathrm{gram}$ [7]. Untuk meningkatkan nilai kalor dari briket sekam padi dibutuhkan biomassa lain untuk dikombinasikan dalam pembuatan briket. Bahan lain yang biasa digunakan pengganti bahan bakar adalah kayu jati. Serbuk kayu dapat dimanfaatkan sebagai bahan pembuatan briket arang karena memiliki nilai kalor yang relatif tinggi [8].

Dalam pemanfaatannya briket dapat digunakan sebagai bahan bakar rumah tangga dengan cara dibakar. Selama pembakaran briket bereaksi dengan oksigen dan dapat menghasilkan gas karbon monoksida $(\mathrm{CO})$ yang berbahaya bagi kesehatan manusia [9].

Pada pembuatan briket ukuran butir yang lebih besar akan menghasilkan briket dengan rongga yang lebih besar. Hal ini akan membuat oksigen dapat masuk ke dalam rongga briket sehingga reaksi oksidasi dapat terjadi lebih cepat bila dibandingkan dengan briket dengan rongga yang lebih kecil. Kenaikan konsentrasi oksigen dalam gas menimbulkan laju pembakaran lebih tinggi. Suhu pembakaran yang lebih tinggi dapat menaikkan laju reaksi dan menyebabkan waktu pembakaran menjadi lebih singkat [10]. Oleh karena itu tujuan dari penelitian ini adalah untuk mengetahui nilai kalor pada briket berbasis sekam padi dengan campuran serbuk gergaji kayu jati berdasarkan ukuran butir briket dan variasi pencampuran bahan, emisi karbon monoksida (CO) yang terbentuk pada saat pembakaran briket, serta mengetahui laju pembakaran briket hingga menjadi abu. 


\section{Metode Penelitian}

Bahan-bahan yang dipakai dalam penelitian ini antara lain sekam padi, serbuk gergaji kayu jati, dan perekat dari tepung tapioka (7\%). Alat-alat yang dipakai dalam penelitian ini antara lain timbangan digital, tungku pirolisis, thermometer infrared, blender, ayakan (40 mesh, 60 mesh, 100 mesh), tungku briket, alat pencetak briket, oven, $\mathrm{CO}$ meter, dan Bomb Calotimeter.

Pembuatan briket terdiri atas 3 tahapan yaitu perlakuan awal, pembuatan briket dan pengujian briket. Perlakuan awal dilakukan pengeringan bahan sekam padi, kulit kopi, dan serbuk gergaji kayu jati. Pengeringan bahan dilakukan dibawah sinar matahari untuk sekam padi dan serbuk gergaji kayu jati selama 1 hari (9 jam). Setelah bahan kering kemudian dilakukan proses karbonisasi dengan kompor pirolisis. Proses karbonisasi sekam padi dilakukan pada suhu $197,7^{\circ} \mathrm{C}$ selama 2 jam, untuk serbuk gergaji kayu jati dilakukan karbonisasi pada suhu $500^{\circ} \mathrm{C}$ selama 1 jam. Selanjutnya proses penghalusan sampel dan penyaringan untuk menentukan ukuran butir sampel dengan menggunakan saringan 40 mesh $(420 \mu \mathrm{m}), 60$ mesh $(250 \mu \mathrm{m})$, dan 100 mesh $(149 \mu \mathrm{m})$.

Proses pencampuran bahan sesuai dengan persentasi perbandingan yang sudah ditetapkan dengan penambahan perekat $7 \%$ dari massa total campuran. Perbandingan konsentrasi pencampuran arang adalah 70:30 dan 50:50 pada setiap ukuran penghalusan bahan. Pencetakan briket menggunakan cetakan berbentuk silinder dengan bagian tengah bolong dengan diameter cetakan $5,2 \mathrm{~cm}$ dan diameter dalam 2,3 cm yang kemudian dilakukan pengepresan dengan menggunakan beban sebesar $45 \mathrm{~kg}$. Setelah dilakukan pencetakan dan pengepresan briket, briket yang telah tercetak dikeringkan menggunakan oven dengan suhu $50^{\circ} \mathrm{C}$ selama 4,5 jam dan menghasilkan briket yang kering dan siap untuk proses pengujian yaitu pengujian nilai kalor, emisi karbon monoksida dan laju pembakaran briket.

Pengujian nilai kalor yang terkandung pada briket dengan menggunakan alat Bomb Calorimeter. Jumlah kalor diukur dalam kalori dan dihasilkan apabila suatu briket dioksidasi dengan sempurna di dalam suatu bomb calorimeter disebut energi total dari briket. Proses pengujian emisi karbon monoksida dan laju pembakaran dilakukan pada saat bersamaan. Selama proses pembakaran briket diamati emisi karbon monoksida menggunakan $\mathrm{CO}$ meter dan diamati suhu pada briket pada interval pada interval waktu 2 menit hingga briket habis terbakar. Sebelum dan setelah dilakukan pembakaran briket ditimbang untuk mengetahui massa briket terbakar guna mengetahui laju pembakaran briket. Pengujian laju pembakaran ini dimaksudkan untuk mengetahui kadar efisiensi bahan bakar briket ini.

\section{Hasil dan Pembahasan}

\subsection{Uji Nilai Kalor}

Pengujian nilai kalor dilakukan dengan alat bomb calorimeter yang tujuan adalah untuk mengetahui besar energi bruto yang terdapat pada briket campuran sekam padi, serbuk kayu jati dan perekat tapioka pada ukuran butir 40 mesh, 60 mesh, dan 100 mesh. Sebelum dilakukan pengujian, sampel ditimbang dengan berat maksimum 1,10 gram yang merupakan berat maksimal yang diizinkan pada alat Bomb Calorimeter. Hasil nilai kalor dapat dilihat pada tabel 1. 
Tabel 1. Hasil Nilai Kalor Briket Campuran Berdasarkan Ukuran Butir Briket

\begin{tabular}{cccc}
\hline Sampel & $\begin{array}{c}\text { Kode } \\
\text { Sampel }\end{array}$ & $\begin{array}{c}\text { Ukuran } \\
\text { Butir } \\
\text { (mesh })\end{array}$ & $\begin{array}{c}\text { Nilai } \\
\text { Kalor } \\
\text { (kal/gr) }\end{array}$ \\
\hline $\begin{array}{c}\text { Sekam Padi : } \\
\text { Serbuk Gergaji } \\
\text { Kayu Jati (70:30) }\end{array}$ & A5 & 40 & 3738 \\
\cline { 2 - 4 } & A3 & 60 & 3420 \\
\hline $\begin{array}{c}\text { Sekam Padi : } \\
\text { Serbuk Gergaji } \\
\text { Kayu Jati (50:50) }\end{array}$ & A6 & 100 & 4330 \\
\cline { 2 - 4 } & A4 & 60 & 3971 \\
\hline
\end{tabular}

Nilai kalor paling besar dari variasi campuran briket terdapat pada konsentrasi campuran 50:50 dengan ukuran butir briket $100 \mathrm{mesh}$, yaitu sebesar $4889 \mathrm{kal} / \mathrm{gr}$. Faktor yang mempengaruhi turunnya nilai kalor dari setiap sampel dikarenakan jumlah dari variasi konsentrasi campur bahan yang semakin turun dan juga ukuran butir briket yang semakin besar.

\subsection{Pengaruh Ukuran Butir Briket Terhadap Emisi gas CO}

Pengamatan emisi gas CO (karbon monoksida) pada penelitian ini dilakukan pada briket dengan ukuran butir 40 mesh, 60 mesh, dan 100 mesh yang dapat dilihat pada Tabel 2.

Tabel 2. Hasil Emisi Karbon Monoksida (CO) Berdasarkan Ukuran Butir Briket

\begin{tabular}{cccccc}
\hline Sampel & $\begin{array}{c}\text { Kode } \\
\text { Sampel }\end{array}$ & $\begin{array}{c}\text { Ukuran } \\
\text { Butir } \\
(\text { mesh })\end{array}$ & $\begin{array}{c}\text { Massa terbakar } \\
(\Delta \mathrm{m})(\text { gram })\end{array}$ & $\begin{array}{c}\text { Waktu } \\
\text { Pembakaran } \\
\text { Briket (sekon) }\end{array}$ & $\begin{array}{c}\text { Emisi Karbon } \\
\text { Monoksida } \\
\text { Rata-Rata } \\
(\mathrm{ppm})\end{array}$ \\
\hline $\begin{array}{c}\text { Sekam Padi : } \\
\text { Serbuk }\end{array}$ & A5 & 40 & 45 & 4083 & 535 \\
\cline { 2 - 6 } $\begin{array}{c}\text { Gergaji Kayu } \\
\text { Jati (70:30) }\end{array}$ & A3 & 60 & 57 & 4526,4 & 770 \\
\hline $\begin{array}{c}\text { Sekam Padi : } \\
\text { Serbuk }\end{array}$ & A6 & 40 & 58 & 4749,6 & 658 \\
\hline $\begin{array}{c}\text { Gergaji Kayu } \\
\text { Jati (50:50) }\end{array}$ & A4 & 60 & 56 & 3980,4 & 509 \\
\hline
\end{tabular}

Pada Tabel 2 dapat dilihat bahwa emisi karbon monoksida akan semakin berkurang seiring dengan ukuran butir yang dimiliki briket yang semakin kasar. Pada ukuran butir 100 mesh pada briket sekam padi dengan serbuk gergaji kayu dengan variasi pencampuran bahan 70:30 didapatkan emisi karbon monoksida yaitu sebesar 658 ppm, pada ukuran butir 60 mesh sebesar 770 ppm dan pada ukuran butir 40 mesh sebesar 535 ppm.

Pengamatan dilakukan pula pada briket sekam padi dengan serbuk gergaji kayu dengan variasi pencampuran bahan 50:50 dan didapatkan kadar emisi karbon 
monoksida pada ukuran butir briket 100 mesh sebesar 678 ppm, ukuran butir 60 mesh sebesar 642 ppm, dan pada ukuran butir 40 mesh sebesar 509 ppm.

Dari hasil pengamatan emisi karbon monoksida pada briket dengan variasi pencampuran bahan 70:30 dan 50:50 dapat dilihat, semakin besar ukuran butir briket maka emisi karbon monoksida yang dihasilkan akan semakin rendah. Pada variasi pencampuran bahan 50:50 menghasilkan emisi karbon (CO) paling rendah, hal ini dapat dikatakan briket ini dapat digunakan sebagai bahan bakar yang lebih baik.

\subsection{Pengaruh Ukuran Butir Briket Terhadap Laju Pembakaran}

Hasil laju pembakaran pada penelitian ini dilakukan pada briket dengan ukuran butir 40 mesh, 60 mesh, dan 100 mesh yang dapat dilihat pada Tabel 3. Kecepatan alir udara yang digunakan adalah konstan sebesar $1,8 \mathrm{~m} / \mathrm{s}$.

Tabel 3. Laju pembakaran berdasarkan ukuran butir briket

\begin{tabular}{|c|c|c|c|c|}
\hline Sampel & $\begin{array}{c}\text { Kode } \\
\text { Sampel }\end{array}$ & $\begin{array}{l}\text { Ukuran } \\
\text { Butir } \\
\text { (mesh) }\end{array}$ & $\begin{array}{c}\text { Waktu } \\
\text { pembakaran } \\
\text { briket } \\
\text { (sekon) }\end{array}$ & $\begin{array}{c}\text { Laju } \\
\text { Pembakaran } \\
\text { (gram/sekon) }\end{array}$ \\
\hline \multirow{3}{*}{$\begin{array}{l}\text { Sekam Padi : } \\
\text { Serbuk } \\
\text { Gergaji Kayu } \\
\text { Jati (70:30) }\end{array}$} & A5 & 40 & 4083 & 0,0110 \\
\hline & A3 & 60 & 4526,4 & 0,0126 \\
\hline & A1 & 100 & 4749,6 & 0,0122 \\
\hline \multirow{3}{*}{$\begin{array}{l}\text { Sekam Padi : } \\
\text { Serbuk } \\
\text { Gergaji Kayu } \\
\text { Jati }(50: 50)\end{array}$} & A6 & 40 & 3980,4 & 0,0138 \\
\hline & A4 & 60 & 4279,2 & 0,0131 \\
\hline & $\mathrm{A} 2$ & 100 & 5476,8 & 0,0113 \\
\hline
\end{tabular}

Pada Tabel 3 dapat dilihat bahwa semakin besar ukuran butir briket lama waktu pembakaran briket hingga habis menjadi abu semakin cepat sehingga menyebabkan laju pembakaran yang dihasilkan semakin cepat. Pada variasi pencampuran 70:30 briket sekam padi dengan serbuk gergaji kayu jati didapat laju pembakaran yang semakin cepat seiring dengan kekasaran ukuran butir briket.

Berdasarkan ukuran butir briket pada variasi komposisi pencampuran bahan 70:30 laju pembakaran dengan ukuran butir briket 40 mesh sebesar 0,0110 gram/sekon, 60 mesh sebesar 0,0126 gram/sekon, dan 100 mesh sebesar 0,0122 gram/sekon. Berdasarkan ukuran butir briket pada variasi komposisi pencampuran bahan 50:50 laju pembakaran dengan ukuran butir briket 40 mesh sebesar 0,0138 gram/sekon, 60 mesh sebesar 0,0131 gram/sekon, dan 100 mesh sebesar 0,0113 gram/sekon.

Salah satu faktor yang mempengaruhi laju pembakaran adalah densitas yang dimiliki oleh briket. Ukuran butir briket yang lebih besar akan menyebabkan densitas pada briket yang semakin kecil sehingga laju pembakaran yang terjadi akan semakin cepat dan briket yang ada akan semakin cepat habis terbakar. Hasil nilai densitas briket berdasarkan ukuran butir briket dapat dilihat pada tabel 4. Jika dilihat keseluruhan dapat diketahui bahwa semakin besar ukuran butir briket laju 
pembakaran yang dihasilkan akan semakin cepat. Briket dengan ukuran partikel yang halus akan menyebabkan partikel penyusun dari briket akan semakin kompak sehingga menyebabkan sulitnya oksigen yang masuk dan menyebabkan semakin lamanya waktu pembakaran dan semakin lambatnya laju pembakaran.

Tabel 4. Nilai Densitas Berdasarkan Ukuran Butir Briket

\begin{tabular}{cccc}
\hline Sampel & $\begin{array}{c}\text { Kode } \\
\text { Sampel }\end{array}$ & $\begin{array}{c}\text { Ukuran } \\
\text { Butir } \\
(\text { mesh })\end{array}$ & $\begin{array}{c}\text { Densitas } \\
\text { (gram/cm3 })\end{array}$ \\
\hline $\begin{array}{c}\text { Sekam Padi : Serbuk } \\
\text { Gergaji Kayu Jati } \\
\text { (70:30) }\end{array}$ & A5 & 40 & 0,483 \\
\cline { 2 - 4 } & A3 & 60 & 0,533 \\
\hline $\begin{array}{c}\text { Sekam Padi : Serbuk } \\
\text { Gergaji Kayu Jati } \\
\text { (50:50) }\end{array}$ & A6 & 100 & 0,512 \\
\cline { 2 - 4 } & A2 & 60 & 0,459 \\
\hline
\end{tabular}

Jika dibandingkan dengan variasi komposisi campuran briket laju pembakaran yang paling rendah terdapat pada sampel briket campuran sekam padi dengan serbuk gergaji kayu jati 70:30 dengan ukuran butir briket 40 mesh sebesar 0,0110 gram/sekon. Laju pembakaran yang paling tinggi terdapat pada sampel briket campuran sekam padi dengan serbuk gergaji kayu jati 50:50 dengan ukuran butir briket 40 mesh sebesar 0,0138 gram/sekon.

\section{Kesimpulan}

Emisi karbon monoksida (CO) semakin berkurang seiring dengan ukuran butir yang dimiliki briket yang semakin kasar. Pada variasi pencampuran bahan sekam padi dan serbuk gergaji kayu jati 50:50 dengan ukuran butir 40 mesh menghasilkan emisi karbon (CO) paling rendah, hal ini dapat dikatakan briket ini dapat digunakan sebagai bahan bakar yang lebih baik. Laju pembakaran pada penelitian ini dilakukan pada briket dengan ukuran butir 40 mesh, 60 mesh, dan 100 mesh dan kecepatan alir udara yang digunakan adalah konstan. Semakin kasar ukuran briket maka laju pembakaran yang dihasilkan akan semakin cepat dan briket semakin cepat habis terbakar. Laju pembakaran yang paling tinggi terdapat pada sampel briket campuran sekam padi dengan serbuk gergaji kayu jati 50:50 dengan ukuran butir briket 40 mesh sebesar 0,0138 gram/sekon dengan nilai kalor sebesar 3971 $\mathrm{kal} / \mathrm{gr}$.

\section{Ucapan terima kasih}

Terimakasih kepada Direktorat Riset dan Pengabdian Pada Masyarakat Universitas Padjadjaran yang telah memberikan dana dan fasilitas melalui Hibah Riset Internal Universitas Padjadjaran Tahun Anggaran 2017

\section{Daftar Pustaka}

1. I. Kholiq, "Pemanfaatan energi alternatif sebagai energi terbarukan untuk mendukung subtitusi bbm," Jurnal IPTEK, vol. 19, hal. 75-91, 2015.

2. Dewan Energi Nasional, Outlook Energi Indonesia 2014. Jakarta. 
3. S. Yokoyama, "Buku Panduan Biomassa Asia: Panduan untuk Produksi dan Pemanfaatan Biomassa.," Jepang: The Japan Institute of Energy, 2008.

4. Supriyatno dan M. Crishna, "Studi Kasus Energi Alternatif Briket Sampah Lingkungan Kampus POLBAN Bandung," Prosiding Seminar Nasional Teknik Kimia "Kejuangan" Pengembangan Teknologi Kimia untuk Pengolahan Sumber Daya Alam Indonesia, no. 21, hal. 1-9, 2010.

5. M. E. A. Satmoko, "Pengaruh Variasi Temperatur Cetakan Terhadap Karakteristik Kayu Sengon Pada Tekanan Kompaksi 6000 Psig," Universitas Negeri Semarang, 2013.

6. Sarjono, "Studi Eksperimental Perbandingan Nilai Kalor Briket Campuran Bioarang Sekam Padi dan Tempurung Kelapa," hal. 11-18, 2013.

7. Badan Standarisasi Nasional, "Briket Arang Kayu," 2000. [Daring]. Tersedia pada: http://sisni.bsn.go.id/index.php/sni_main/sni/detail_sni/5781. [Diakses: 04-Agu-2017].

8. A. Setiawan, O. Andrio, dan P. Coniwanti, "Pengaruh Komposisi Pembuatan Biobriket dari Campuran Kulit Kacang dan Serbuk Gergaji Terhadap Nilai Pembakaran," Jurnal Teknik Kimia, vol. 18, no. 2, hal. 9-16, 2012.

9. S. Fardiaz, Polusi Air dan Udara. Kansius, 1992.

10. S. Jamilatun, "Sifat-Sifat Penyalaan dan Pembakaran Briket Biomassa, Briket Batubara dan Arang Kayu," Jurnal Rekayasa Proses, vol. 2, no. 2, hal. 37-40, 2008. 